\title{
IDENTIFIKASI PIGMEN FIKOBILIPROTEIN PADA KAPPAPHYCUS ALVAREZII DALAM PELARUT BUFFER FOSFAT DENGAN METODE FREEZE THAW CYCLE
}

\author{
Noor Rohmah Mayasari ${ }^{*}$, Karseno ${ }^{2}$, Retno Setyawati ${ }^{3}$ \\ 1. S1 Ilmu Gizi, STIKes Mitra Keluarga, Bekasi-Indonesia \\ 2. S1 Ilmu dan Teknologi Pangan, Universitas Jenderal Soedirman, Purwokerto-Indonesia \\ 3. S1 Ilmu dan Teknologi Pangan, Universitas Jenderal Soedirman, Purwokerto-Indonesia
}

*Korespondensi: Noor Rohmah Mayasari | STIKes Mitra Keluarga | noor.rohmah@gmail.com

\begin{abstract}
Abstrak
Pendahuluan: Kappaphycus alvarezii mengandung pigmen fikobiliprotein yang terdiri dari fikoeritrin, fikosianin, dan alofikosianin. Pigmen tersebut telah banyak dimanfaatkan dalam bidang kesehatan, seperti sebagai fotosensitiser pada terapi kanker. Penelitian ini bertujuan untuk mengetahui pengaruh konsentrasi pelarut buffer fosfat dan waktu freeze thaw cycle pada jumlah fikobiliprotein dalam Kappaphycus alvarezii dan mengidentifikasi pigmen tersebut.

Metode: Penelitian ini adalah penelitian eksperimental dengan menggunakan Rancangan Acak Lengkap (RAL). Faktor yang diuji adalah konsentrasi pelarut yang terdiri dari 4 taraf konsentrasi dan waktu freeze thaw cycles yang terdiri dari 3 taraf sehingga diperoleh 12 kombinasi perlakuan dengan 2 kali ulangan.

Hasil: Penelitian ini menunjukkan bahwa konsentrasi buffer fosfat dan lama freeze thaw cycle tidak berpengaruh pada jumlah pigmen fikobiliprotein. Hasil penelitian menunjukkan bahwa pigmen fikobiliprotein berwarna merah muda; memiliki tiga puncak absorbansi maksimal pada 565, 545; dan $498 \mathrm{~nm}$ dan lebih stabil pada $\mathrm{pH} 7$.
\end{abstract}

Kesimpulan: Identifikasi pigmen fikobiliprotein pada penelitian ini menunjukkan bahwa Fikoeritrin adalah pigmen yang paling dominan.

Kata Kunci : Fikobiliprotein, Kappaphycus alvarezii, Identifikasi, Buffer fosfat, Freeze thaw cycle.

Diterima 2 April 2019; Accepted 30 Juni 2019

\section{PENDAHULUAN}

Kappaphycus alvarezii (dulunya dikenal dengan Eucheuma cottonii) merupakan jenis rumput laut merah yang tersebar di wilayah perairan Indonesia dan telah banyak dibudidayakan karena memiliki nilai ekonomis tinggi karena kandungan karaginannya (Anggadireja, 2008). Selain mengandung karaginan, Kappaphycus alvarezii menghasilkan pigmen. Pigmen-pigmen alami pada sumber daya hayati khususnya rumput laut terbukti mempunyai berbagai khasiat yang memberikan manfaat bagi manusia. Creczuga (1985) mengatakan bahwa, alga terutama alga merah mengandung pigmen istimewa yakni fikobiliprotein.

Fikobiliprotein terdiri dari tiga komponen yaitu, fikosianin, fikoeritrin, dan alofikosianin. Fikobiliprotein sudah dimanfaatkan secara luas di bidang kesehatan, sebagai fotosensitiser pada terapi penyakit kanker (Niu et al., 2006) dan dibidang pangan sebagai pengawet makanan karena menunjukkan aktivitas antioksidan (Santiago-Santos et al., 2004). Adanya keistimewaan yang dimiliki fikobiliprotein, maka banyak penelitian yang dilakukan untuk mengembangkan manfaat fikobilliprotein. Beberapa industri biokimia seperti Seta Biochemical, Invitrogen, dan Flogen telah mengembangkan fungsi serta menjual fikobiliprotein secara komersial dengan harga yang sangat tinggi. Lyophylize R-fikoeritrin dihargai dengan $\$ 250 / 5 \mathrm{mg}$ setara dengan kurang lebih 2 juta rupiah/5mg. Pigmen tersebut diisolasi dari sianobakteri dan rumput laut merah.

Melihat hal itu, maka Indonesia memiliki potensi Sumber Daya Alam yang dapat dimanfaatkan untuk menghasilkan pigmen tersebut salah satunya dari pemanfaatan Kappaphycus alvarezii. Meskipun Kappaphycus alvarezii telah dimanfaatkan sebagai bahan pembuat karaginan tapi warna khasnya sengaja di hilangkan melalui proses bleaching sebelum diolah menjadi karaginan. Apabila pigmen ini bisa dimanfaatkan, nilai Kapphapycus alvarezii dapat ditingkatkan.

Ekstraksi pigmen fikobiliprotein dapat dilakukan menggunakan buffer fosfat (Naguit \& Tisera, 2009) dan metode freeze thaw. Freeze thaw cycle merupakan salah satu metode perusakan sel, dengan pembentukan kristal es pada sel. Hal yang mempengaruhi pembentukan kristal es yaitu lama freeze thaw cycle. Efektifitas pelarutan pigmen pada sel Kappaphycus alvarezii dipengaruhi oleh konsentrasi pelarut buffer fosfat. 
Metode freeze thaw cycle dan penggunaan buffer fosfat tersebut dapat mengisolasi pigmen fikobiliprotein dari Kappaphycus alvarezii. Namun untuk mengetahui pigmen fikobiliprotein yang terkandung pada Kappaphycus alvarezii perlu dilakukan identifikasi terlebih dahulu terkait sifat-sifat yang dimiliki fikobiliprotein, diantaranya melihat warna pigmen secara visual, mengukur panjang gelombang maksimal fikobiliprotein, identifikasi didukung dengan stabilitas pigmen pada variasi $\mathrm{pH}$ dan kandungan fikobiliprotein. Penelitian ini bertujuan untuk: 1) Mengidentifikasi fikobiliprotein pada Kappaphycus alvarezii. 2) Mengetahui perlakuan freeze thaw cycle dan konsentrasi pelarut buffer fosfat yang dapat mengisolasi fikobiliprotein pada Kappaphycus alvarezii secara optimal.

\section{METODE}

Rancangan yang digunakan dalam penelitian ini adalah Rancangan Acak Lengkap (RAL). Faktor yang dicoba terdiri dari konsentrasi pelarut buffer fosfat $(\mathrm{K})$ dan waktu freeze thaw cycles $(\mathrm{W})$. Konsentasi pelarut buffer fosfat $(\mathrm{K})$ terdiri dari $\mathrm{K} 1=0 \mathrm{mM}, \mathrm{K} 2=10 \mathrm{mM}, \mathrm{K} 3=20 \mathrm{mM}, \mathrm{K} 4=50 \mathrm{mM}$; waktu freeze thaw cycles $(\mathrm{W})$ terdiri dari $\mathrm{W} 1=2$ jam freeze dan 2 jam thaw, W2 $=3$ jam freeze dan 3 jam thaw, W3 $=4$ jam freeze dan 4 jam thaw. Sehingga diperoleh dua belas kombinasi perlakuan dengan 2 kali ulangan.

Bahan-bahan yang digunakan dalam penelitian ini adalah Kappaphycus alvarezii dari kepulauan Karimun Jawa, buffer fosfat (Na2HPO4 + NaH2PO4) pH 7, ammonium sulfat, kertas pH, akuades, air bebas ion, kertas saring whatman. Alat-alat yang digunakan dalam penelitian ini adalah freezer (Toshiba), kulkas (Toshiba), erlenmeyer (Pyrex), sentrifus (Sigma 204), spektrofotometer UV-Vis (Shimadzu-Japan), cuvet, termometer, tabung reaksi (Pyrex), pH meter (Sigma), labu ukur $100 \mathrm{ml}$ (Pyrex), pipet ukur $10 \mathrm{ml}$ (Pyrex), $1 \mathrm{ml}$, corong, spatula, cup plastic, plastik, timbangan analitik, timbangan digital. Tahapan ekstraksi pigmen dapat dilihat pada gambar 1.

Variabel yang diamati yaitu visualisasi pigmen Kappaphycus alvarezii, kandungan fikobiliprotein, spektrum absorbansi, stabilitas fikobiliprotein pada variasi $\mathrm{pH}$. Cara analisa visualisasi pigmen Kappaphycus alvarezii : Pigmen Kappaphycus alvarezii yang diisolasi menggunakan metode freezethawing cycle dan pelarut buffer fosfat diamati secara visual. Pengamatan dilakukan dengan membandingkan warna pigmen yang dihasilkan dengan skala warna pada kamus warna Munsell Chart. Kandungan fikobiliprotein adalah penjumlahan dari C-PC (fikosianin), C-APC (alofikosianin), C-PE (fikoeritrin) yangditentukan dengan persamaan sebagai berikut yang dimodifikasi dalam $\mu \mathrm{g} / \mathrm{ml}$ :
$\mathrm{C}-\mathrm{PC}(\mu \mathrm{g} / \mathrm{ml})$
$=\{($ OD620 $-0,7$ OD650)/7.38 $\} \times 1000$
C-APC $(\mu \mathrm{g} / \mathrm{ml})$
$=\{($ OD650 - 0,19 OD620)/5,65 $\} \times 1000$
C-PE $(\mu \mathrm{g} / \mathrm{ml})$
$=\{(\mathrm{OD} 540-2,8(\mathrm{C}-\mathrm{PC})-1,34(\mathrm{C}-\mathrm{APC}) / 12,7\} \times 1000$ (Soniet al., 2006).

Perhitungan kandungan fikobiliprotein ditentukan dengan mengukur (OD/ Optical Density) pigmen pada panjang gelombang 540,620,650 nm dan menghitungnya dengan persamaan tersebut. Spektrum absorbansi: Pigmen yang didapatkan disiapkan dalam cuvet kemudian diletakkan pada spektrofotometer dan dilihat spektrum absorbansinya. Penentuan spektrum absorbansi menggunakan spektrofotometer UVVis yang diamati pada panjang gelombang 200-700 $\mathrm{nm}$ (Liu et al., 2000). Stabilitas fikobiliprotein pada variasi $\mathrm{pH}$ : Stabilitas pigmen diamati pada variasi $\mathrm{pH}(6,7$, dan 8), selanjutnya pengecekan dilakukan dengan mengukur absorbansinya menggunakan spektrofotometer (Galland-Irmouli et al., 2000).

Data jumlah fikobiliprotein dianalisis dengan uji ragam (uji F) untuk mengetahui ada tidaknya pengaruh dalam masing-masing faktor perlakuan dan interaksinya terhadap variabel yang diamati. Analisis lebih lanjut dilakukan apabila hasil analisis menunjukkan pengaruh yang nyata dengan menggunakan Duncan's Multiple Range Test (DMRT) pada taraf 5 persen. Data disajikan dalam grafik hubungan absis dan koordinat, yang disesuaikan dengan variabel yang diamati. Penjelasan yang diberikan merupakan penjelasan deskriptif hasil isolasi dan identifikasi pigmen Kappaphycus alvarezii.

\section{HASIL}

\section{Visualisasi pigmen Kappaphycus alvarezii.}

Perlakuan freeze thaw cycle dan konsentrasi buffer fosfat pada Kappaphycus alvarezii menghasilkan pigmen dengan visualisasi warna merah muda (pink). Warna pigmen Kappaphycus alvarezii di notasikan antara 5R 7/8 dan 5R 6/8. Ini berarti kedua notasi tersebut secara kualitatif memiliki hue dan chroma yang sama, hanya dibedakan dengan value yang menegaskan adanya perbedaan jumlah sinar yang dipancarkan yang berpengaruh pada terangnya warna tersebut (kedua notasi menjelaskan warna pink, value 7 berarti 
lebih terang dari value 6).

\section{Spektrum Absorbansi Pigmen Kapphaphycus alvarezii}

Hasil penelitian ini menunjukkan pigmen fikobiliprotein memiliki tiga titik puncak yaitu pada 498; 536; $565 \mathrm{~nm}$ dengan absorbansi masing-masing 2,$189 ; 2,118 ; 1,823$. Sedangkan absorbansinya pada panjang gelombang $620 \mathrm{~nm}$ dan $650 \mathrm{~nm}$ adalah 1,229 dan 1,147 (Gambar 2).

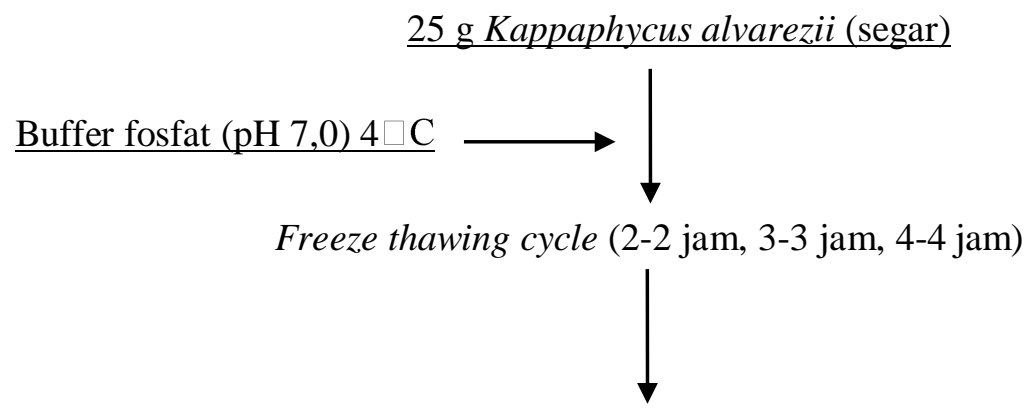

Sentrifuse (3500xg, $30 \mathrm{~min}$, dalam kondisi gelap)

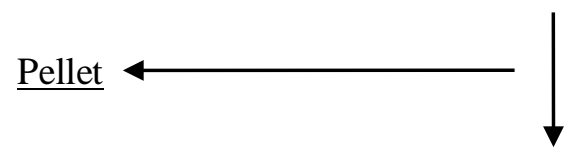

\section{$\underline{\text { Supernatan }}$}

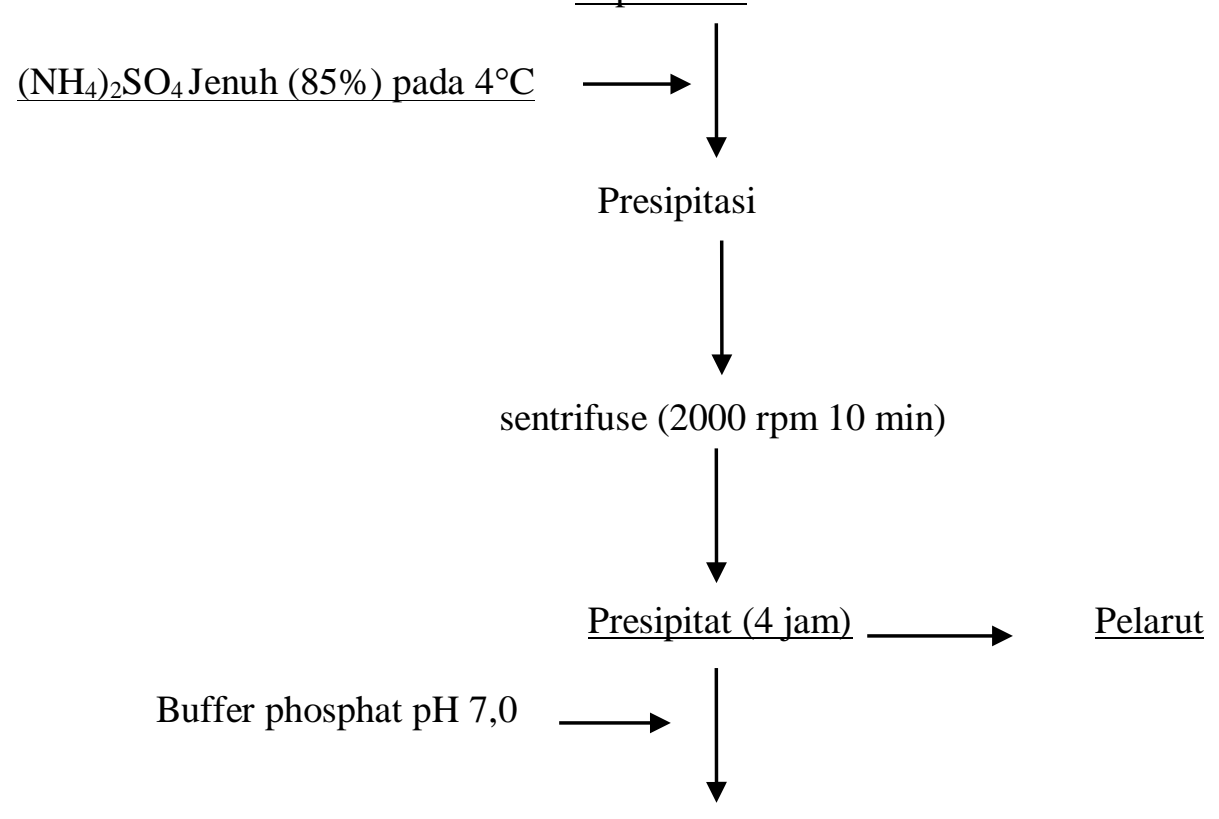

Pelarutan kembali

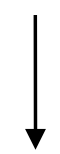

Ekstrak pigmen Kappaphycus alvarezii

Gambar 1. Tahapan ekstraksi Kappaphycus alvarezii (metode freeze thaw cycle).

\section{Kandungan Pigmen Fikobiliprotein Kappaphycus alvarezii}

Pigmen fikobiliprotein adalah pigmen yang terkandung di dalam rumput laut Kappaphycus alvarezii. 
Kandungan fikobiliprotein adalah penjumlahan dari fikoeritrin, fikosianin, dan alofikosianin. Berdasarkan analisis ragam, didapatkan hasil bahwa waktu freeze thaw cycle dan konsentrasi buffer fosfat tidak memberikan pengaruh nyata terhadap kandungan pigmen Kappaphycus alvarezii. Meskipun hasil analisa menunjunjukkan tidak ada perbedaan pengaruh perlakuan terhadap kandungan pigmen fikobiliprotein, namun berdasarkan grafik rata-rata kandungan fikobiliprotein, pigmen terbanyak dihasilkan dari perlakuan K1W1 (konsentrasi $0 \mathrm{mM}$ dan freeze thaw cycle 2 jam) dengan jumlah sebesar $167 \mu \mathrm{g} / \mathrm{ml}$ (Gambar 4).

\section{Kandungan fikoeritrin, fikosianin, dan alofikosianin}

Fikobiliprotein Kappaphycus alvarezii yang dominan adalah fikoeritrin disusul oleh alofikosianin dan fikosianin. Interaksi konsentrasi buffer fosfat dan freeze thaw cycle yang menghasilkan pigmen fikoeritrin dan fikosianin terbanyak adalah perlakuan K1W1 (konsentrasi $0 \mathrm{mM}$ dan waktu freeze thaw cycle 2 jam), sedangkan alofikosianin terbanyak dihasilkan perlakuan K3W2.

(konsentrasi $20 \mathrm{mM}$ dan waktu freeze thaw cycle 3 jam). Jumlah maksimal kandungan fikoeritrin, fikosianin, dan alofikosianin berturut-turut dari perlakuan tersebut adalah $70 \mu \mathrm{g} / \mathrm{ml}, 30 \mu \mathrm{g} / \mathrm{ml}$, dan $68 \mu \mathrm{g} / \mathrm{ml}$ (Gambar 4). Pengaruh tunggal konsentrasi buffer fosfat yang dapat mengekstrak fikoeritrin maksimal adalah $50 \mathrm{mM}$ sedangkan fikosianin dan alofikosianin adalah $20 \mathrm{mM}$ (Gambar 5). Waktu freeze thaw cycle yang mampu mengekstrak maksimal ketiga pigmen tersebut adalah waktu 2 jam (Gambar 6).

Alofikosianin pada pigmen Kappaphyus alvarezii jumlahnya lebih sedikit dari fikoeritrin dan lebih banyak dari fikosianin. Pigmen alofikosianin terbanyak dengan jumlah $68 \mu \mathrm{g} / \mathrm{ml}$ adalah perlakuan K3W2 (konsentrasi $20 \mathrm{mM}$ dan waktu freeze thaw cycle 3 jam) (Gambar 4). Pengaruh tunggal konsentrasi buffer fosfat dan waktu freeze thaw cycle yang dapat menghasilkan pigmen alofikosianin terbanyak adalah konsentrasi buffer fosfat $20 \mathrm{mM}$ (Gambar 5)dan waktu freeze thaw cycle 3 jam (Gambar 6).

\section{Stabilitas Fikobiliprotein pada berbagai pH.}

Pigmen fikobiliprotein diuji stabilitasnya pada $\mathrm{pH} 6, \mathrm{pH} \mathrm{7,} \mathrm{dan} \mathrm{pH}$ 8. Hasil pengukuran spektrofotometer pada penelitian ini menunjukkan grafik pigmen Kappaphycus alvarezii lebih stabil pada pH 7 dan menurun stabilitasnya pada pH 6 dan pH 8 (Gambar 3).

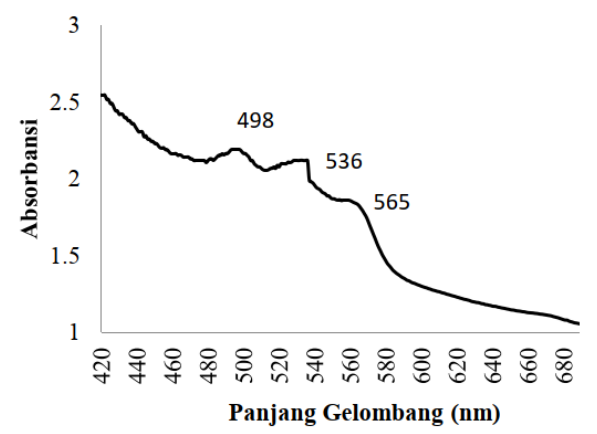

Gambar 2. Nilai absorbansi pigmen Kappaphycus alvarezii (K3W1) pada panjang gelombang 420-700 nm.

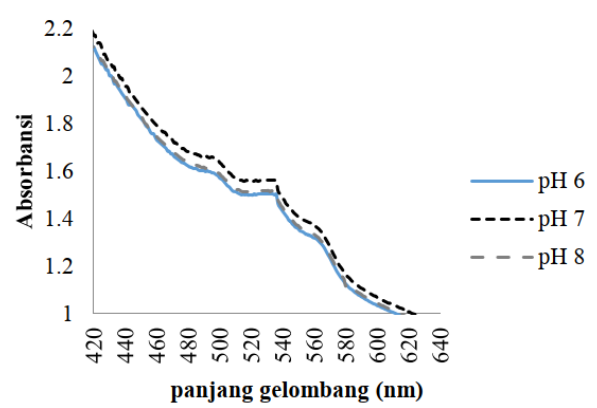

Gambar 3. Stabilitas pigmen Kappaphycus alvarezii (K3W1) pada berbagai pH. 


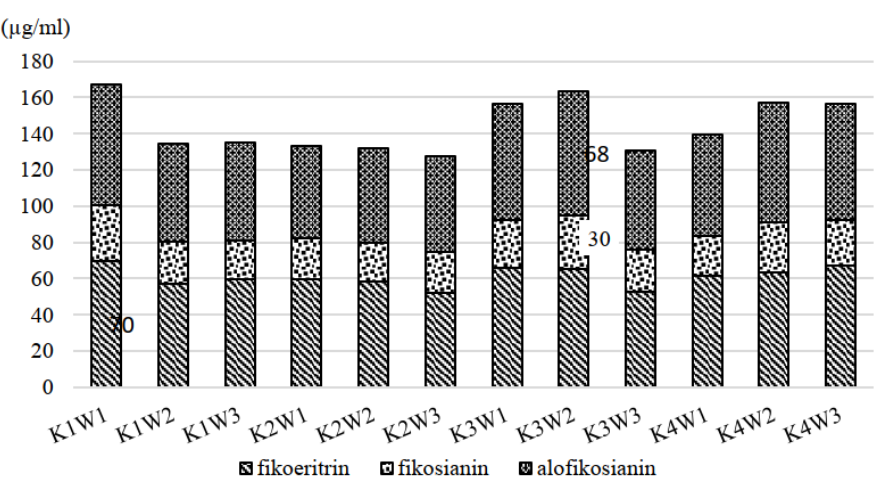

Keterangan : konsentrasi buffer fosfat ; K1 $=0 \mathrm{mM}, \mathrm{K} 2=10 \mathrm{mM}, \mathrm{K} 3=20 \mathrm{mM}, \mathrm{K} 4=50 \mathrm{mM}$. waktu freeze thaw cycle; W1 $=2$ jam cycle, $\mathrm{W} 2=3$ jam cycle, $\mathrm{W} 3=4$ jam cycle.

Gambar 4. Interaksi konsentrasi buffer fosfat dan freeze thaw cycle terhadap kandungan fikobiliprotein Kappaphycus alvarezii.

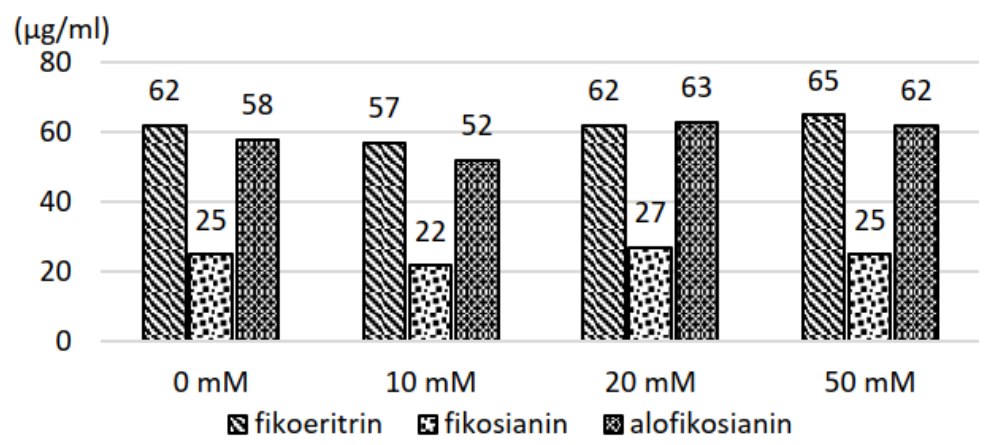

Gambar 5. Konsentrasi buffer fosfat (mM) terhadap rata-rata kandungan fikobiliprotein.

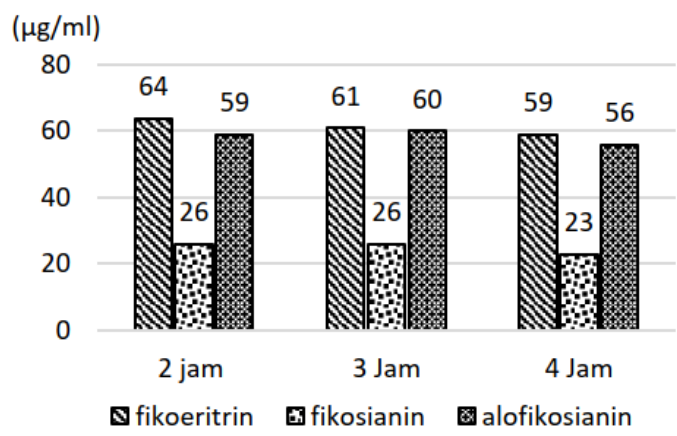

Gambar 6. Waktu freeze thaw cycle terhadap rata-rata kandungan fikobiliprotein.

\section{PEMBAHASAN}

Metode penelitian yang digunakan pada penelitian ini adalah metode freeze thaw cycle. Pigmen fikobiliprotein terdapat pada stroma yang terdapat pada membran tilakoid (Sun et al., 2008). Kappaphycus alvarezii mengandung metabolit primer berupa karaginan. Proses ekstraksi yang dilakukan sebisa mungkin meminimalisir kontaminan berupa karaginan. Mekanisme metode ekstraksi freeze thaw menurut Soni et al. (2006) yaitu sel-sel dari bahan mengalami kerusakan karena terbentuknya kristal-kristal es tajam selama proses freezing kemudian menyebabkan sel mengalami pengerutan selama thawing. Ekstraksi sel dengan metode ini secara maksimal diperoleh pada suhu $-25 \square \mathrm{C}$ dan $4 \square \mathrm{C}$ dari proses freeze thaw. Niu et al. (2007) menyatakan proses freeze thaw cycle $-20 \square \mathrm{C}$ dan peningkatan suhu pada $4 \square \mathrm{C}$ menyebabkan sel pecah (lysis) dan mengeluarkan fikobiliprotein. Proses ekstraksi dengan freeze thaw dilakukan melalui beberapa kali cycle. 
Proses freeze thaw cycles yang digunakan adalah empat kali cycles akan menghasilkan pigmen fikosianin (bagian dari fikobiliprotein) maksimal, fikobiliprotein dapat dilindungi dari fotodenaturasi lanjut, jika penyimpanan dilakukan dalam gelap suhu $4^{\circ} \mathrm{C}$ (Soni et al.,2006). Pigmen yang terekstrak selanjutnya dimurnikan menggunakan ammonium sulfat. Ammonium sulfat merupakan garam yang paling sering digunakan untuk mengendapkan protein karena memiliki daya larut tinggi didalam air, relatif tidak mahal (Scopes, 1982). Pemurnian dilakukan selama 4 jam pada suhu $4 \square \mathrm{C}$ sampai terjadi presipitasi protein (Patel et al., 2005).

Penambahan ammonium sulfat akan menyebabkan molekul air berikatan dengan ion-ion garam, semakin banyak garam semakin banyak pula ion-ion garam berikatan dengan molekul air sehingga menyebabkan penarikan selubung air yang mengeliliingi permukaan protein. Protein akan saling berinteraksi, beragregasi, dan kemudian mengendap (salting-out). Presipitat dilarutkan melalui peristiwa salting-in. Setelah tahap ini pigmen kasar menjadi lebih murni, karena kontaminan sudah jauh berkurang.

Setelah proses isolasi pigmen menggunakan kombinasi kedua metode tersebut, dilakukan proses identifikasi pigmen fikobiliprotein yang meliputi: Visualisasi, identifikasi spektrum absorbansi, dan stabilitas pigmen pada berbagai $\mathrm{pH}$.

\section{Visualisasi pigmen Kappaphycus alvarezii.}

Visualisasi pigmen fikobiliprotein pada Kappaphycus alvarezii adalah merah muda (pink). Munsell Chart menotasikan pigmen ini dengan 5R 6/8 dan 5R 7/8 yang artinya pigmen in berwarna merah muda terang dan agak gelap. Visualisasi ini mewakili adanya kandungan pigmen fikobiliprotein pada Kappaphycus alvarezii. Asumsinya, semakin gelap warnanya maka kandungan fikobiliprotein semakin tinggi. Visualisasi dan notasi warna ini identik dengan pigmen fikoeritrin yang merupakan salah satu jenis fikobiliprotein. Graham \& Wilcox (2000) menyatakan rumput laut merah memiliki warna merah muda sampai merah tua, karena kandungan pigmen fikoeritrin.

\section{Spektrum Absorbansi Pigmen Kapphaphycus alvarezii}

Fikobiliprotein Kappaphycus alvarezii memiliki 3 puncak yaitu pada 498, 536, $565 \mathrm{~nm}$. Beberapa penelitian terdahulu menyebutkan, pigmen Porphyridium cruentum mempunyai 3 puncak yang cocok dengan puncak fikoeritrin $(565,545$, dan $498 \mathrm{~nm})$ serta tidak ada puncak fikosianin yang dilihat pada panjang gelombang maksimum $620 \mathrm{~nm}$ dan alofikosianin pada panjang gelombang maksimum $650 \mathrm{~nm}$. Hal ini berarti alofikosianin dan fikosianin yang terkandung dalam ekstrak tidak menunjukkan jumlah yang berarti (Roman et al., 2002). Galland-Irmouli et al. (2000) menambahkan, hasil spektrofotometer pigmen fikoertirin dari Palmaria palmata yang dipurifikasi menghasilkan enam puncak pada panjang gelombang 300 sampai $700 \mathrm{~nm}$. Tiga puncak yang terdeteksi sesuai dengan puncak fikoeritrin $(565,545$, dan $499 \mathrm{~nm})$. Dua puncak ditemukan pada panjang gelombang $620 \mathrm{~nm}$ (panjang gelombang maksimum fikosianin), dan $650 \mathrm{~nm}$ (panjang gelombang maksimum alofikosianin) dan panjang gelombang $320 \mathrm{~nm}$ (panjang gelombang ini tidak teridentifikasi sebagai pigmen apapun).

Membandingkan hasil penelitian ini dengan penelitian tersebut, maka grafik spektrum absorbansi pada pigmen Kappaphycus alvarezii memiliki puncak seperti fikosanin pada 565 dan $498 \mathrm{~nm}$ serta tidak memiliki puncak pada panjang gelombang alofikosianin dan fikosianin yaitu 650 dan $620 \mathrm{~nm}$. Hal tersebut menunjukkan bahwa pigmen Kappaphycus alvarezii mengandung fikoeritrin, sedangkan alofikosianin dan fikosianin yang terkandung pada pigmen Kappaphycus alvarezii tidak menunjukkan jumlah yang berarti.

\section{Stabilitas Fikobiliprotein pada berbagai pH.}

Hasil pengukuran spektrofotometer pada penelitian ini menunjukkan grafik pigmen Kappaphycus alvarezii lebih stabil pada $\mathrm{pH} 7$ dan menurun stabilitasnya pada $\mathrm{pH} 6$ dan $\mathrm{pH}$

8. Liu et al. (2005) menyatakan bahwa pigmen fikoeritrin pada Polysiphonia urceolata lebih stabil pada $\mathrm{pH} 7$ dan stabilitasnya menurun jika terjadi penurunan $\mathrm{pH}$. Absorbansi pigmen fikoeritrin pada $\mathrm{pH} 7$ lebih tinggi dibandingkan dengan $\mathrm{pH}$ 6. Galland-Irmouli et al. (2000) menyatakan fikoeritrin memiliki stabilitas yang baik pada kisaran $\mathrm{pH}$ 3.5-9.5. Absorbansi pigmen fikobiliprotein $\mathrm{pH} 6.5$ lebih baik dibandingkan dengan $\mathrm{pH} 8$ dan 4.5. Pigmen fikoeritrin pada penelitian ini memiliki sifat lebih stabil pada $\mathrm{pH}$ netral dibandingkan dengan $\mathrm{pH}$ asam atau basa. Stabilitas pigmen fikobiliprotein pada Kappaphycus alvarezii ini mendukung identifikasi, bahwa pigmen fikobiliprotein adalah fikoeritrin. 


\section{Kandungan Fikobiliprotein}

Hasil analisa ragam menyatakan bahwa metode isolasi (konsentrasi buffer fosfat dan freeze thaw cycle) tidak mempengaruhi jumlah pigmen fikobiliprotein yang dihasilkan, namun apabila di analisa dengan menggunakan grafik kandungan rata-rata pigmen fikobiliprotein, maka didapatkan beberapa hal yang menarik untuk di bahas. Kandungan fikobiliprotein terbanyak dihasilkan dari perlakuan K1W1 (konsentrasi $0 \mathrm{mM}$ dan freeze thaw cycle $2 \mathrm{jam}$ ) (Gambar.4). Fikobiliprotein sangat larut dalam air (Glazer, 1989). Air merupakan pelarut polar yang dapat melarutkan zat terlarut ionik dan zat polar lainnya (Herlina, 2008). Protein merupakan zat polar dan zat yang mempunyai interaksi ionik dengan air. Hal itu yang menyebabkan pada konsentrasi $0 \mathrm{mM}$ fikobiliprotein terekstrak paling maksimal.

Waktu 2 jam merupakan waktu yang optimal mengekstrak pigmen fikobiliprotein dan penyusunnya. Hal ini disebabkan oleh sifat pigmen yang tidak tahan pada kondisi penyimpanan suhu rendah (freezer). Fikobiliprotein sebaiknya disimpan pada suhu $4 \square$ C dan keadaan gelap (Soni et al., 2006) sedangkan dalam penelitian ini fikobiliprotein terkondisikan dalam keadaan freeze pada suhu $-20 \square \mathrm{C}$. Oleh karena itu waktu freeze thaw cycle 2 jam adalah waktu yang paling baik untuk ekstraksi fikobiliprotein. Waktu ekstraksi yang lebih lama justru menurunkan stabilitas pigmen tersebut.

Fikobiliprotein merupakan protein dan dapat larut pada buffer fosfat. Buffer fosfat merupakan buffer basa yang dapat menjaga kestabilan $\mathrm{pH}$ larutan (Purba, 2002). Buffer fosfat merupakan campuran asam fosfat dan basa konjugasinya ( $\mathrm{NaH}_{2} \mathrm{PO} 4$ dan Na2HPO4). Penambahan buffer fosfat akan menyebabkan $\mathrm{pH}$ larutan stabil sehingga mengurangi terjadinya kerusakan pada pigmen. Diduga ekstraksi fikoeritrin, fikosianin, dan alofikosianin dipengaruhi oleh konsentrasi buffer fosfat dan waktu freeze thaw cycle.

Kandungan fikoeritrin, fikosianin, dan alofikosianin

Meskipun secara umum pengaruh tunggal waktu freeze thaw cycle 2 jam adalah perlakuan yang mampu mengekstrak pigmen fikoeritrin, fikosanin, dan alofikosianin terbanyak, namun konsentrasi buffer fosfat yang dapat mengekstrak maksimal ketiga pigmen tersebut berbeda. Fikoeritrin terbanyak dihasilkan pada pelarut buffer fosfat $50 \mathrm{mM}$ sedangkan fikosianin dan alofikosianin terbanyak dihasilkan pada pelarut buffer fosfat $20 \mathrm{mM}$. Hal ini diduga terkait dengan perbedaan berat molekul ketiga pigmen tersebut. Fikoeritrin memilki molekul yang besar yaitu $240 \mathrm{kDa}$ (protein oligomer) (Rossano et al., 2003), fikosianin dan alofikosianin memiliki berat molekul yang berdekatan yaitu berturut-turut $121 \mathrm{kDa}$ (protein triomer) dan $104 \mathrm{kDa}$ (Protein triomer) (Columbia Biosciences, 2011).

Protein mudah mengalami perubahan stuktur (denaturasi) karena perubahan $\mathrm{pH}$. Berkelman et al. (2004) mengatakan bahwa $\mathrm{pH}$ dan kekuatan ion larutan mempunyai pengaruh pada kelarutan protein, sehingga ditambahkan buffer pada saat persiapan sampel. Semakin tinggi konsentrasi buffer fosfat maka semakin tinggi pula stabilitas larutan dari perubahan $\mathrm{pH}$. Stabilitas ini dapat menjaga keseimbangan protein dalam larutan. Oleh karena itu molekul fikoerititrin yang besar memerlukan konsentrasi buffer fosfat yang tinggi untuk mengimbangi larutan agar mempunyai stabilitas tinggi selama proses ekstraksi. Konsentrasi fosfat yang tinggi dapat menjaga stabilitas $\mathrm{pH}$. Sehingga fikoeritrin diekstrak maksimal pada konsentrasi buffer fosfat $50 \mathrm{mM}$ sedangkan fikosianin dan alofikosianin pada konsentrasi $20 \mathrm{mM}$.

Meskipun konsentrasi buffer fosfat dan waktu freeze thaw cycle tidak berpengaruh terhadap jumlah pigmen fikobiliprotein, fikoeritrin, fikosianin, dan alofikosianin akan tetapi secara deskriptif interaksi perlakuan K1W1 (konsentrasi buffer fosfat $0 \mathrm{mM}$ dan waktu freeze thaw cycle 2 jam) menghasilkan pigmen fikobiliprotein, dan fikoeritrin terbanyak sedangkan interaksi pelakuan K3W2 (konsentrasi buffer fosfat $20 \mathrm{mM}$ dan waktu freeze thaw cycle 3 jam) menghasilkan pigmen fikosianin dan alofikosianin terbanyak. Hasil penelitian ini belum menghasilkan kesimpulan yang senada. Penggunaan konsentrasi buffer fosfat $0 \mathrm{mM}$ dan 2 jam freeze thaw cycle sudah mampu mengekstrak pigmen fikobiliprotein. Apabila dibandingkan dengan perlakuan yang lain, perlakuan minimal ini adalah paling efektif. Akan tetapi penggunaan konsentrasi $0 \mathrm{mM}$ mungkin akan menurunkan stabilitas pigmen tersebut selama penyimpanan.

\section{KESIMPULAN}

Berdasarkan penelitian ini disimpulkan bahwa konsentrasi buffer fosfat dan waktu freeze thaw cycle tidak berpengaruh terhadap kandungan fikobiliprotein pada Kappaphycus alvarezii. Meski demikian, secara 
analisa deskriptif konsentrasi buffer fosfat $0 \mathrm{mM}$ dan waktu 2 jam freeze thaw cycle adalah metode yang efektif untuk mengekstrak pigmen fikobiliprotein. Hasil identifikasi menunjukkan bahwa pigmen fikobiliprotein berwarna merah muda (notasi Munsell Colour Chart 5R 7/8); memiliki tiga puncak absorbansi maksimal pada 565, 545; dan $498 \mathrm{~nm}$ serta lebih stabil pada pH 7 yang mengindikasikan bahwa pigmen yang dominan pada fikobiliprotein Kappaphycus alvaezii adalah fikoeritrin. Melihat hasil penelitian ini peneliti menyarankan untuk dilakukan penelitian lebih lanjut tentang pengaruh konsentrasi buffer fosfat dan waktu freeze thaw cycle terhadap stabilitas pigmen fikobiliprotein pada Kappaphycus alvarezii.

\section{REFERENSI}

Anggadireja, J.T., A., Zatnika, H., Purwoto, S., Istini. 2008. Rumput Laut. Penebar swadaya, Jakarta.

Berkelman, T., M. G. Brubacher, and H. Chang. 2004. Important Factors Influencing Protein Solubility for 2-D Electrophoresis. BioRadiation $114:$ 30-32

Czeczuga, B. 1985. Light-Harvesting Phycobiliprotein Pigments of the Red Alga Leptosomia simplex from the Antartic. Journals Polar Biology 4 : 179-181.

Columbia $\quad$ Biosciences, $2011 . \quad$ Allophycocyanin. $\quad$ (On-line). http://www.columbiabiosciences.com/Technology/Introduction-to- phycobiliproteins. diakses pada 6 juni 2011.

Galland-Irmouli, A.V., L. Lucon, M. Villaume., C. Mrabet, N. T. Gueant, J. L Fleurence J., 2000. One Step Purification of R-phycoerithrin from red macroalga Palmaria palmate using preparative polyacrilamide gel electrophoresis. J. cromatogr. B.Biomed. Sci. Appl. 739, 117-123.

Glazer, A.N. 1989. Directional Energy Transfer in Photosyntetic Antenna. Journal of Biological Chemistry. $264: 1-4$.

Graham, L. E. dan L. W. Wilcox. 2000. Algae. Prentice-hall, Inc, USA.

Herlina, E. 2008. Upaya Peningkatan Kelarutan Hidroklortiazida dengan Penambahan Surfaktan Tween 60. Skripsi. Fakultas Farmasi Universitas Muhamadiyah Surakarta, Surakarta.

Liu, L., X. Chen, X. Zhang, Y. Zhang, B. Zhou. 2005. One-step Chromatography Method for Efficient Separation and Purification of R-phycoerithrin from Policiphonia urceolata. Journal of Biotechnology 116:91-100.

Naguit, M. R. dan W. L. Tisera. 2009. Pigmen Analysis on Eucheuma Denticulatum (Colllins \& Hervey) and Kappaphycus alvarezii (Doty) Cultivars Cultured at Different Depths. The Threshold IV :29-37.

Niu, J-F., G-C. Wang, C-K. Tseng. 2006. Method for Large-Scale Isolation and Purification of RPhycoerithrin from Red Alga Polysiphonia urceolata Grev. Journals Protein Expression and Purification 49(1):23-31.

Patel, A., S. Mishra, R. Pawar, P. K. Ghosh, 2005. Purification and Characterization of C-Phycocyanin from Cyanobacterial Species of Marine and Freshwater Habitat. Journals Protein Expression and Purification 40(2):248-255.

Purba, M. 2002. Kimia untuk SMA Kelas XI. Erlangga, Jakarta.

Román, R.B., J. M. Alvárez-Pez, F. G. A. Fernández, E. M. Grima. 2002. Recovery of Pure Bphycoerythrin from the Microalga Porphyridium cruentum. Journal of Biotechnology 93 : 73-85.

Rossano, R., N. Ungaro, A. D'Ambrosio, G.L Liuzzi, dan R. Riccio. 2003. Extracting and Purifyng Rphycoerythrin from Mediterranean red algae Corralina elongate Ellis \& Solander. Journal of Biotechnol. 101:289-293.

Santiago-Santos, Ma.C., T. Ponce-Noyola, R. Olvera-Ramírez, J. Ortega-López and R.O. Caňizarez Villanueva.2004. Extraction and purification of phycocyanin from Calotrix sp. J. Process Biochemistry. 39 : 2047-2052.

Scopes, R.K. 1982. Protein Purification Principles and Practice. Springer-Verlag, New York.

Soni, B., B. Kalavadia, U. Trivedi, D. Madamwar. 2006. Extraction purification and characterization of phycocyanin from oscillatoria quadripunctulata-isolated from the rocky shorcs of bet-dwarka, Gujarat, India. Journals Process Biochemistry 41(9):2017-2023.

Sun, L., S. Wang, X. Gong, M. Zhao, X. Fu, L. Wang. 2008. Isolation, Purification and Characteristics of R-phycoerithrin from Marine Macroalgae Heterosiphonia japonica. Journals Protein Expression and Pufification 6(2):146-154. 